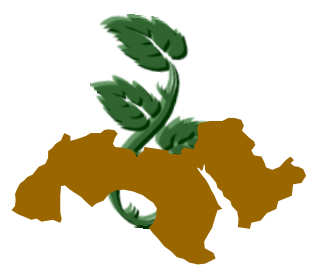

\title{
EFFECT OF HEAT TREATMENT ON THE NUTRITIVE VALUE AND RESIDUES OF SOME SYNTHETIC PESTICIDES IN FRESH BOLTI FISH
}

\author{
Nevein S. Ahmed ${ }^{1}$ and El-Gammal I. Om El-Saad ${ }^{2}$ \\ 1- Central Agricultural Pesticide Laboratory, Dokki, Giza, Egypt. \\ 2- Food Sci. and Tech. Department, Faculty of Home Economics, Al Azhar Univ., Tanta, Egypt
}

Keywords: Nutritive value, Organochlorine (OC), Synthetic pyrethroid (SP), Residue, Fish, Cooking methods, Grilling

\section{ABSTRACT}

Fresh Bolti fish (Tilpia nilotica) collected randomly from 9 different markets in Ismailia Governorate for evaluation the effect of grilled fish by the method used in grillrooms and houses on the concentration of pesticide residues found and the nutritive value. Results revealed that decrease in the estimated parameters i.e. moisture, crude protein, fat and ash by grilling, this decrease were 6.07, $2.63,4.07$ and $1.56 \%$, respectively. On the contrary, carbohydrates behaved another behavior that there was an obvious increase ranged from $1.98 \%$ to $2.92 \%$.

Fresh and grilled fish were analyzed to detect 12 organochlorine $(\mathrm{OC})$ and 7 synthetic pyrethroid (SP) pesticides with a mean level on a lipid basis. Gas Liquid Chromatography equipped with Electron Capture Detector GC-ECD was used to detect the contamination in the samples.

The results showed that p,p'-DDE isomer was dominated over the other isomers in all analyzed fish samples, followed by $\alpha$ - $\square$ isomer of hexachlorocyclohexane. The concentrations of $\mathrm{OC}$ residues were higher than SP pesticides in all fish muscles. Also, the fresh fish muscle recorded higher concentrations of the evaluated pesticides than the grilled one.

\section{INTRODUCTION}

Ismailia, a medium-size Egyptian city, has a population of 270,000 and an annual growth rate of
$3.8 \%$. it is considered the East gate for Egypt to Asia continental and Arab countries (Zahran 2010). Fish has been recognized as a high quality protein and fat that are completely digested and assimilated in body than that of any other protein and fat. Fish oils are a rich natural sources of long -chain poly unsaturated fatty acids those of the $\omega-3$ series. Beneficial health effects of $\omega-3$ are well demonstrated and include the prevention of a number of disease, such as coronary heart diseases, inflammation, hypotriglyceridemic effect, allergies, hypertension, arthritis, autoimmune disorders, and cancer (Sahena et al 2010). Fish are constantly exposed to chemicals in polluted and contaminated waters as a good indicator of contaminants in aquatic systems (Tuzen and Soylak (2007). Fish exposed to pesticides in four primary ways (1) dermally, direct absorption through the skin by swimming in pesticide-contaminated waters, (2) breathing, by direct uptake of pesticides through the gills during respiration, (3) orally, by drinking pesticide-contaminated water and (4) feeding on dead insects which poisoned by insecticides or contaminated prey (Louis et al 2009). Governments in developing countries do their best to cover malnutrition in animal protein by increasing fish production from rivers and aquaculture (farmed). Twenty percent from protein requirements in Egypt come from sea. The production of fish in Egypt as recorded by the annual report of organization for aquarium development Nasr City, Cairo, for the Nile, Lake and farm fish, Bolti fish represents about $38.20 \%$ of total fish products in Egypt (Ammar 2004). The nutritive value of fish can be affected by grilling as one of the most easy home-made consumed cooking method. OC and SP are non-systemic with high solubility in fats 
present in fish muscles. In Egypt, OC pesticides were used from the 1950s until 1981. This class of pesticides is characterized by persistence in the environment and the tendency to accumulate in aquatic organisms. Residues and metabolites of many $O C$ are very stable with long half lives in the environment (Abou-Arab, 1999 \& UNEP 2002). SP pesticides are a class of lipophilic insecticide very easily degraded in the natural environment, sensitive to sunlight and relatively low toxicity as compared with $\mathrm{OC}$, we have to consider the less cost of OC and SP than any other pesticides (Demoute 2006 \& Miyamoto et al 1981). Although Egypt is the largest pesticide market in Arabian countries and the fourth largest importer of pesticides among developing countries, there are no regular monitoring programs for identification and determination of pesticides in the environment (Abou-Arab, 1999; El Nemr and Abd-Allah 2004 \& Yamashita et al 2000). The pesticides applied on land eventually find their way to the aquatic environment, thus contamination occurred and subsequently get accumulated in Fish (Kaur et al 2008 ) in which we are interested in.

The main objectives of the present study was to evaluate:

1- The gross chemical composition in fish (fresh and grilled bolti fish) including moisture, crude protein, fat, ash contents and carbohydrates.

2-The daily requirements for the illustrated estimates for children and adults.

3- Determination of the presence of OC and SP pesticide residues in fresh fish muscles.

4- Studying the effect of grilling on residues determined.

\section{MATERIALS AND METHODS}

\section{Fish Sampling}

Fish samples were collected from 9 different local markets at Ismailia governorate and then individually placed into numbered clean polyethylene bags.

The mean weight and length of fish were $301.56 \pm 45.64 \mathrm{~g}$ and $22.24 \pm 2.11 \mathrm{~cm}$ respectively.

\section{Technological Method}

Fish samples are subjected to the grilling process which was carried out with an electrically operated grill at $180^{\circ} \mathrm{C}$ for $30 \mathrm{~min}$.

\section{1- Chemical composition analysis of fish con- tents}

Fish flesh of each fresh and grilled fish were minced using meat mincer and were chemically analyzed for moisture, crude protein, ash and ether extract content per 100gram basis on dry weight according to the AOAC (2000). Carbohydrates were determined by difference 100- (moisture + crud protein + ether extract+ ash). Total solids were calculated by the following equation:

\section{Weight of fresh or grilled fish flesh - its moisture content \\ $T . S=\overline{\text { Weight of fresh or grilled fish flesh }}$ $X 100$}

\section{2- Analysis of pesticide residue in fish samples}

\section{2-1 Standard Pesticides Used}

All samples were analyzed for 12 organochlorine and 7 pyrethroid pesticides. Pesticides standard solution prepared in n-hexane : $\alpha-\mathrm{HCH}$, $\beta-\mathrm{HCH}, \gamma-\mathrm{HCH}$, Heptachlor, Aldrin, Heptachlorepoxide, Dieldrin, Endrin, p,p'-DDE, o,p'-DDT, p,p'DDD and p,p'-DDT all at $1 \mathrm{ng} / \mathrm{l} \mu \mathrm{l}$, Endrin, at 2 ng/ul, Meothrin, Tetramethrin, Cyhalothrin, Cypermethrin, Fenvelerate, Deltamethrin all at $5 \mathrm{ng} / \mu \mathrm{l}$.

\section{2-2 Extraction and Clean up}

Extraction and clean up in fish muscles to determine pesticide residues were carried out using the method applied by UNEP/IOC/IAEA, (1989, 1991); IOC (1993), Khaled et al (2004), Nasr et al (2009) and Bordet et al (2002).

All solvents were of pesticide residue analysis grade and the purity of all reagents was carefully checked.

\section{2-3 Determination}

Analysis of OC and SP pesticides in fish muscle fat were carried out with an Agilent Gas Chromatograph, model 7890 equipped with Microelectron capture detector (GC-ECD) fitted with HP-

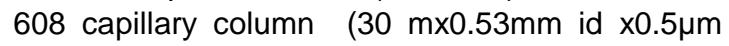
film thickness). The column temperature was programmed as initial temperature $160^{\circ} \mathrm{C}$ for $2 \mathrm{~min}$ then increased at the rate of $5^{\circ} \mathrm{C} / \mathrm{min}$, till $260^{\circ} \mathrm{C}$ then hold $2 \mathrm{~min}$. The detector and injector temperatures were maintained at $320^{\circ} \mathrm{C}$ and $260^{\circ} \mathrm{C}$, respectively, with nitrogen carrier gas flow rate of 3 $\mathrm{ml} / \mathrm{min}$. 


\section{2-4 Recovery Tests}

Recovery analyses were carried out on samples fortified using $0.5,1$ and 1.5 of the permitted limit each. The mean recovery of all pesticides used were tabulated in Table (1).

Table 1. Average recovery percentage, standard deviation, retention times and method detection limits

\begin{tabular}{|c|c|c|c|}
\hline Pesticides & $\begin{array}{c}\% \\
\text { Recovery } \\
\text { SD } \\
\end{array}$ & $\begin{array}{c}\text { Retention } \\
\text { times (Rt) } \\
(\mathrm{min})\end{array}$ & $\begin{array}{l}\text { LOD } \\
\left(\mathrm{ng} \mathrm{g}^{-1}\right)\end{array}$ \\
\hline$\alpha-\mathrm{HCH}$ & $86.52 \pm 0.73$ & 5.41 & 0.03 \\
\hline $\mathrm{B}-\mathrm{HCH}$ & $82.12 \pm 0.82$ & 7.04 & 0.04 \\
\hline $\mathrm{\gamma}-\mathrm{HCH}$ & $81.01 \pm 1.12$ & 8.08 & 0.05 \\
\hline Heptachlor & $85.52 \pm 0.65$ & 9.28 & 0.06 \\
\hline Aldrin & $83.87 \pm 0.59$ & 10.84 & 0.06 \\
\hline $\begin{array}{c}\text { Heptachlor } \\
\text { epoxide }\end{array}$ & $81.94 \pm 1.12$ & 13.04 & 0.03 \\
\hline Dieldrin & $80.23 \pm 1.84$ & 16.15 & 0.03 \\
\hline P,P'-DDE & $82.01 \pm 1.35$ & 17.18 & 0.06 \\
\hline Endrin & $91.86 \pm 0.76$ & 18.35 & 0.03 \\
\hline O,P'-DDT & $87.34 \pm 0.33$ & 20.24 & 0.03 \\
\hline$P, P^{\prime}-D D D$ & $90.27 \pm 1.06$ & 21.21 & 0.02 \\
\hline P,P'-DDT & $93.79 \pm 1.19$ & 25.75 & 0.01 \\
\hline Meothrin & $94.26 \pm 0.34$ & 26.17 & 0.03 \\
\hline Tetramethrin & $95.22 \pm 0.83$ & 29.59 & 0.02 \\
\hline Cyhalothrin & $93.48 \pm 0.37$ & 30.21 & 0.02 \\
\hline Permethrin & $94.05 \pm 0.67$ & 30.72 & 0.03 \\
\hline Cypermethrin & $92.98 \pm 0.52$ & 34.76 & 0.02 \\
\hline Fenvelerate & $93.82 \pm 0.58$ & 38.36 & 0.02 \\
\hline Deltamethrin & $92.67 \pm 0.74$ & 40.41 & 0.02 \\
\hline
\end{tabular}

\section{RESULTS AND DISCUSSION}

\section{1-The gross chemical composition}

Gross chemical composition as percentage of both fresh and grilled Bolti fish are demonstrated in Table (2). It could be observed from its analytical data that the sequence of the average values of moisture, ether extract, crude protein and ash contents are graded in reduction at considerable levels ranged from 76.88 to $70.81 \%, 8.33$ to $4.26 \%$, 80.49 to $77.86 \%, 7.28$ to 5.72 and 1.98 to $2.92 \%$ respectively for the illustrated estimates. Consider- ing the average value of total solids led to detect that the heat used in grilling has increased the total solids values from $23.13 \%$ in fresh samples to $29.07 \%$ in grilled samples. These results were in agreement with those of Galhom, (2002) who found that moisture content of some Egyptian water fish ranged from 70.00 to $79.00 \%$ and the nile fishes had crude protein and ash contents at levels ranged from 15.20 to $21.50 \%$ and 1.38 to $1.62 \%$ as wet weight respectively.

Darweish and Shams El-Din, (1993), also stated that the ash content of Bolti fish were 4.73 and $1.05 \%$ basis as dry and wet weight respectively.

Table (3) presents data of the contribution of gross chemical composition of the grilled Bolti fish to the daily requirements as average values of protein, ash, fat and energy for both children from 7-10 years and adults. These data show that these estimates have contributed to the daily requirements for children at levels of $80.79,92.78,6.20$ and $0.73 \%$ respectively basis on wet weight. The same estimates achieved $35.91,84.35,8.27$ and 0 $.54 \%$ of these contribution for adult males and $45.24,87.90,8.27$ and $0.728 \%$ respectively as wet weight for adult females. The same table illustrated that the contribution of grilled fish to the daily requirements of energy for the adult males and females are negligible. The nutritive value was nearly in agreement with the work of Amir (1972).

\section{II- Detection of OC and SP pesticides in fish muscle}

The concentrations of $\mathrm{OC}$ and SP pesticides in the fresh and grilled bolti fish collected from 9 markets in Ismailia governorate are presented in Table (4). The results are expressed in $\mathrm{ng} \mathrm{g}^{-1}$ fish fat.

From Table (4), the data proved that the high content of fats present in the fresh muscle, the increasing of the residues found. By grilling method, the fats drips away with the toxic chemicals dissolved in. $p, p^{\prime}-D D E, \quad p, p^{\prime}-D D D$ were the main metabolites of DDT detected with highest concentrations of $6.28,4.04 \mathrm{ng} / \mathrm{g}$, respectively with $100 \%$ frequency percentage in case of $p, p^{\prime}-D D E$ and $25 \%$ of the other metabolite. The effect of grilling method decreased the residues to 1.83 and 1.34 with percentage reduction of 57.93 and $55.57 \%$, respectively. Also $\alpha-\mathrm{HCH}$ detected in high frequency percentage $75 \%$ with a mean value of 2.12 decreasing to $0.62 \mathrm{ng} / \mathrm{g}$ with reduction percentage of $70.75 \%$ after the grilling method. From Table (4) we notice that the grilling method 
Table 2. Effect of Grilling on the Gross Chemical Composition of Bolti fish flesh. (g/100g dry weight)

\begin{tabular}{|c|c|c|c|c|c|c|c|}
\hline Treatment & $\begin{array}{c}\text { Range and } \\
\text { average }\end{array}$ & Moisture & $\begin{array}{c}\text { Ether } \\
\text { extract }\end{array}$ & $\begin{array}{c}\text { Crud } \\
\text { protein }\end{array}$ & Ash & ${ }^{*}$ Carbohydrates & $\begin{array}{c}\text { Total } \\
\text { Solids }\end{array}$ \\
\hline Fresh flesh & Maximum & 77.53 & 10.43 & 82.97 & 8.07 & 2.59 & 25.26 \\
& Minimum & 74.72 & 5.61 & 76.01 & 6.34 & 1.55 & 22.47 \\
& Average & 76.88 & 8.33 & 80.49 & 7.28 & 1.98 & 23.13 \\
\hline Grilled flesh & Maximum & 72.77 & 5.11 & 80.25 & 6.38 & 3.48 & 31.07 \\
& Minimum & 68.27 & 3.28 & 76.37 & 5.00 & 2.65 & 27.23 \\
& Average & 70.81 & 4.26 & 77.86 & 5.72 & 2.92 & 29.07 \\
\hline
\end{tabular}

* basis on dry weight $\quad{ }^{* \star}$ Calculated by difference

Table 3. Contribution of protein, ash, fat and energy of grilled Bolti fish to the Daily nutritive requirement for children from (7-10 years) and adults

\begin{tabular}{|c|c|c|c|c|c|c|c|}
\hline & \multirow{2}{*}{$\begin{array}{c}\text { Component } \\
\%\end{array}$} & $\begin{array}{c}\text { *Average } \\
\text { value }\end{array}$ & \multicolumn{5}{|c|}{ Daily nutritive requirements for children (7-10) and adults } \\
\cline { 3 - 8 } & $\begin{array}{c}7-10 \text { years } \\
\text { (gm) }\end{array}$ & $\begin{array}{c}\text { Contribution } \\
\% \\
\text { per100gm }\end{array}$ & Males & $\begin{array}{c}\text { Contribution } \\
\% \\
\text { per100gm }\end{array}$ & Females & $\begin{array}{c}\text { Contribution } \\
\% \\
\text { per100gm }\end{array}$ \\
\hline Protein & 22.62 & $* 28.00$ & 80.79 & $63.00 \mathrm{gm}$ & 35.91 & $50.00 \mathrm{gm}$ & 45.24 \\
Ash & 1.67 & ${ }^{* *} 1.80$ & 92.78 & $1.98 \mathrm{gm}$ & 84.53 & $1.90 \mathrm{gm}$ & 87.90 \\
Fat & 1.24 & ${ }^{* * *} 1.00$ & 06.20 & $15.00 \mathrm{gm}$ & 8.27 & $15.00 \mathrm{gm}$ & 8.27 \\
Carbohydrate & 0.850 & 20.00 & - & ---- & --- & -- & --- \\
Energy(Kcal) & 14.56 & 2000 & 00.73 & 2700 (Kcal) & 0.54 & 2000 & 0.728 \\
\hline
\end{tabular}

${ }^{*}$ Basis on wet weight

** Recommended Dietary Allowances, $10^{\text {th }}$ Edition (1989).

${ }^{\star \star \star}$ Recommended Dietary Allowances for Indian Swaminathan (1993).

eliminate the SP pesticides detected in the fresh fish muscle. We have to notice that none of the detected pesticides are exceed the permissible limit set by the international Commissions FAO (1983).

The main reasons for the increasing presence of these $\mathrm{OC}$ in the environment are, first, the cheap and ready availability of chlorine gas on an industrial scale led to the production of chlorinated compounds of technological importance. Secondly, many of these polychlorinated organic compounds, cyclic in structure, and highly thermo-stable in character, which were resistant to biodegradation; and thirdly, the uncontrolled use and discharge of these chemicals resulted in methods for their detection led to the growing awareness of their increasing presence in the ecosystem (Smith and Gangolli 2002). Many literatures are found the predominancy of $p, p^{\prime}-D D E$ over the other $p, p^{\prime}-$ isomers in all studied fish as El Nemr and Abd Allah (2004), but they conclude that the level of organochlorine pesticides contamination in fish from the studied governorates is relatively low and should not pose a health risk to consumers. Abou Arab et al (1995) found that total DDT were predominant in fish samples in both seasons indicating the high stability of these compounds in the environment. Nasr et al (2009) found that p,p'DDE residue were the most abundant in fish sample.

The cooking method as grilling led to non detectable of SP pesticides residues, this is may be due to the high temperature used in grilling $\left(180^{\circ} \mathrm{C}\right)$, this statement agreed with Lutnicka et al (1999). 
Table 4. The minimum, maximum, standard deviation of the mean ( $\mathrm{ng} \mathrm{g}^{-1} \mathrm{fish}$ fat), frequency percentage in fresh and grilled fish

\begin{tabular}{|c|c|c|c|c|c|c|c|c|c|}
\hline \multirow[b]{2}{*}{ Pesticides } & \multicolumn{4}{|c|}{ Fresh } & \multicolumn{5}{|c|}{ Grilled } \\
\hline & Min & Max & Mean \pm SD & $\begin{array}{c}\% \\
\text { Frequency }\end{array}$ & Min & Max & Mean \pm SD & $\begin{array}{c}\% \\
\text { Frequency }\end{array}$ & $\begin{array}{c}\% \\
\text { Reduction }\end{array}$ \\
\hline$\alpha-\mathrm{HCH}$ & $\mathrm{ND}$ & 2.85 & $2.12 \pm 0.92$ & 75.00 & ND & 1.03 & $0.62 \pm 0.120$ & 25.00 & 70.75 \\
\hline $\mathrm{B}-\mathrm{HCH}$ & ND & 1.06 & $0.78 \pm 0.45$ & 66.66 & ND & 0.82 & $0.42 \pm 0.11$ & 11.11 & 46.15 \\
\hline $\mathrm{Y}-\mathrm{HCH}$ & ND & 0.79 & $0.58 \pm 0.31$ & 25.00 & ND & ND & ND & 0.00 & $>91.37^{\star}$ \\
\hline Heptachlor & ND & 1.61 & $1.49 \pm 0.72$ & 25.00 & ND & 1.06 & $0.85 \pm 0.21$ & 16.66 & 42.95 \\
\hline Aldrin & ND & ND & ND & 0.0 & ND & ND & ND & 0.0 & -- \\
\hline $\begin{array}{l}\text { Heptachlor } \\
\text { epoxide }\end{array}$ & ND & ND & ND & 0.0 & ND & ND & ND & 0.0 & -- \\
\hline Dieldrin & ND & 1.92 & $1.69 \pm 0.19$ & 25.00 & ND & 0.52 & $0.66 \pm 0.37$ & 27.27 & 60.94 \\
\hline P,P'-DDE & ND & 6.28 & $4.35 \pm 1.03$ & 100.00 & ND & 2.45 & $1.83 \pm 0.417$ & 50.00 & 57.93 \\
\hline Endrin & ND & 2.02 & $1.89 \pm 0.59$ & 25.00 & ND & 0.93 & $0.71 \pm 0.135$ & 5.55 & 62.43 \\
\hline O,P'-DDT & ND & 0.79 & $0.71 \pm 0.14$ & 50.00 & ND & 0.48 & $0.43 \pm 0.12$ & 25.00 & 39.43 \\
\hline P,P'-DDD & ND & 4.04 & $3.03 \pm 0.22$ & 16.66 & ND & 2.95 & $1.34 \pm 0.0056$ & 25.00 & 55.77 \\
\hline P,P'-DDT & ND & 0.27 & $0.22 \pm 0.03$ & 8.33 & ND & 0.14 & $0.12 \pm 0.04$ & 5.55 & 45.45 \\
\hline Meothrin & ND & ND & ND & 0.0 & ND & ND & ND & 0.0 & -- \\
\hline Tetramethrin & $\mathrm{ND}$ & ND & ND & 0.0 & ND & ND & ND & 0.0 & -- \\
\hline Cyhalothrin & ND & 0.92 & $0.83 \pm 0.22$ & 11.11 & ND & ND & ND & 0.0 & $>97.59^{\star}$ \\
\hline Permethrin & ND & 0.81 & $0.70 \pm 0.31$ & 8.33 & ND & ND & ND & 0.0 & $>98.57^{\star}$ \\
\hline Cypermethrin & ND & ND & ND & 0.0 & ND & ND & ND & 0.0 & -- \\
\hline Fenvelerate & $\mathrm{ND}$ & ND & ND & 0.0 & ND & ND & ND & 0.0 & -- \\
\hline Deltamethrin & ND & ND & ND & 0.0 & ND & ND & ND & 0.0 & -- \\
\hline
\end{tabular}

ND: Not detectable (below the LOD)

${ }^{*}$ According to the LOD

Certain pyrethroids such as cyhalothrin and permethrin where the isobutenyl group attached to the cyclopropane moiety has been altered, are slightly more stable to sunlight than other pyrethroids which agreed with U.S. Department of Health and Human Services (2003).

\section{Conclusions}

The grilling processes of fish basis on dry weight, showed significant decrease in its nutritive value for fat, crude protein and ash but showed fairly increase in the total solids and carbohydrates.

As the fats drips away by grilling cooking method, this will reduce toxic chemicals that have accumulated in fatty tissue. None of residues of OC or SP pesticides in fresh or grilled fish muscles exceed the permissible limits set by the FAO.

\section{REFERENCES}

Abou-Arab, A.A.K. (1999). Behavior of pesticides in tomatoes during commercial and home preparation. Journal of Food Chemistry, 65: 509-514.

Abou-Arab, A.A.K.; M.N.E. Gomaa; A. Badawy and K. Naguib (1995). Distribution of organochlorine pesticides in Egyptian aquatic ecosystem. Food Chemistry, 54: 141-146.

Ammar, A.K. (2004). Effect of Some Preparation and Technological Processes on Bolti Fish Quality. p. 1. Ph.D. Thesis, Dept. Food Techn., Fac. Of Agric., Tanta Univ., Egypt.

Amir, S.A. (1972). Effect of Processing on Nutritive Value of Some Egyptian Fish. p. 19. M.Sc. Thesis, Dept. Food Tech., Fac. of Agric., Cairo Univ. Egypt.

AOAC, (2000). Official Methods of the Association of Analytical Chemists 17 ${ }^{\text {th }}$ Ed. 1: 588 . Published by the Association of Official Agriculture Chemists, Washington, D.C. Gaithersburg, MD, USA.

Bordet, F.; D. Inthavong and J.M. Fremy (2002). Interlaboratory study of a multiresidue gas chromatographic method for determination of organochlorine and pyrethroid pesticides and 
polychlorobiphenyls in milk, fish, eggs and beef fat. Journal of AOAC International 85(2): 1398-1409.

Darweish, P.M. and N.M. Shams El-Din (1993). Chemical Composition and storage stability of fish as influenced by cooking. Smoking and irradiation. Egypt. J. Agric. Res. 71(3): 777.

Demoute, Jean-Pierre (2006). A brief review of the environmental fate and metabolism of pyrethroids. Pesticide Science, 27(4): 375-385.

El Nemr, A. and A.M.A. Abd-Allah (2004). Organochlorine contamination in some marketable fish in Egypt. Chemosphere 54: 1401-1406.

FAO (1983). Compilation of Legal Limits for Hazardous Substances in Fish and Fishery Products. FAO Fishery Circular, 464: 5-100.

Galhome, G.F.A. (2002). Dried Fish Products. p. 10. M.Sc. Thesis, Dep. Food Techn., Fac. Agric., Cairo Univ., Egypt.

Kaur, M.; J.K. Sharma; J.P. Gill; R.S.I. Aulakh; J.S. Bedi and B.S. Joia (2008). Determination of organochlorine pesticide residues in freshwater fish species in Punjab, India. Bull. Environ Contam. Toxicol., 80: 154-157.

Khaled, A.; A. El-Nemr; T.O. Said; A. El-Sikaily; and A.M.A. Abd-Alla (2004). Polychlorinated biphenyls and chlorinated pesticides in mussels from the Egyptian Red Sea coast. Chemosphere 54: 1407-1412.

IOC, (1993). Chlorinated biphenyls in open ocean waters: sampling, extraction, clean-up and instrumental determination. Manual and Guides No. 27, Paris: Intergovernmental Oceanographic Commission, UNESCO 36.

Louis, A.H.; Diana L. Weigmann; Patricia Hipkins and Elizabeth R. Stinson (2009). Pesticides and Aquatic Animals: A Guide to Reducing Impacts on Aquatic Systems, Virginia State University www.ext.vt.edu, Publication May 1 $1^{\text {st }}, 420-013: 1-24$.

Lutnicka, H.; T. Bogacka and L. Wolska (1999). Degradation of pyrethroids in an aquatic ecosystem model. Water Research 33(16): 34413446.

Miyamoto, J.; K.I. Beynon; T.R. Roberts; R.J. Hemingway and $H$. Swaine (1981). The chemistry, metabolism and residue analysis of synthetic pyrethroids, IUPAC Reports on Pesticides 15. Pure \& Appl. Chem., 53: 1967- 2022.

Nasr, I.N.; M.H. Arief; A.H. Abdel-Aleem and F.M. Malhat (2009). Persistent Organic Pollutants (POPs) in Egyptian Aquatic Environment. Journal of Applied Sciences Research, 5(11): 1929-1940.

Recommended Dietary Allowances 10 th Edition (1989). p. 774. National Academy of Sci- ences. Prepared by Food and Nutrition Board. National Research Council. Washington. D.C.

Sahena, F.; I.S.M. Zaidul; S. Jinap; A.M. Yazid; A. Khatib and N.A.N. Norulaini (2010). Fatty acid compositions of fish oil extracted from different parts of Indian mackerel (Rastrelliger kanagurta) using various techniques of supercritical $\mathrm{CO}_{2}$ extraction. Food Chemistry 120(3): 879-885.

Smith, A.G. and S.D. Gangolli (2002). Organochlorine chemicals in seafood: occurrence and health concerns. Food and Chemical Toxicology 40: 767-779.

Swaminatha, N.M. (1993). Handbook of Food and Nutrition. No. 88, PB. No. 1807. Published by the Bangalore Printing and Publishing Co., LTD., Mysore Road, Bangalore 560018.

Tuzen, M. and M. Soylak (2007). Determination of trace metals in canned fish marketed in Turkey. Food Chemistry, 101: 1378-1382.

UNEP/IOC/IAE, (1989). Determination of DDTs and PCBs in selected marine organisms by capillary column gas chromatography, reference methods for marine pollution study No. 40 Nairobi: United Nations Environment Program, 18.

UNEP/IOC/IAE (1991). Sampling of selected marine organisms and sample preparation for the analysis of chlorinated hydrocarbons. Reference methods for marine pollution studies no. 12, revision 2. Nairobi: United Nations Environment Program, 17

UNEP. (2002). United Nations Environment Program Chemicals. Indian Ocean Regional Report. Industry and Economics Division, pp. 15-67. UNEP Chemicals is a part of UNEP's Technology.

U.S. Department of Health and Human Services (September 2003). Public Health Service Agency for Toxic Substances and Disease Registry. Toxicological Profile for Pyrethrins and Pyrethroids. Chapter 2: 1- 15.

Yamashita, N.; Y. Urushigawa; S. Masunaga; M.I. Walash and A. Miyazaki (2000). Organochlorine pesticides in water,sediment and fish from the Nile River and Manzala Lake in Egypt. Int. J. Environ. Anal. Chem. 77: 289303.

Zahran, M.A. (2010): Afro-Asian Mediterranean Coastal Lands, Climate Vegetation. Plant and Vegetation, 4: 1-103. 